\title{
Larvicidal activity of Agave sisalana against Aedes aegypti mosquito, the dengue vector
}

\author{
Fabiola Nunes*, Louise Guimarães, Debora Lacerda, Sandra Mascarenhas, Valdir Braga \\ From 5th Congress of the Brazilian Biotechnology Society (SBBIOTEC) \\ Florianópolis, Brazil. 10-14 November 2013
}

\section{Background}

Dengue is a viral systemic disease caused by an arboviral of Flaviviridae family, affecting about a 700 thousand cases per year in Brazil. It is endemic in tropical regions such as Southeast Asia, South Pacific, East Africa, Caribbean and Latin America. The disease is transmitted by Aedes aegypti (Linnaeus, 1762), a mosquito that is the main target for the disease control through strategies ranging from the larval to the adult combat. The larvicides commonly used to combat the vector, besides being toxic, present drop in larvicide efficacy since the A. aegypti larvae has developed resistance to these products. Thus, the search for new active principles that are effective in combating the mosquito is required. In this sense, Agave sisalana is a plant that is produced in several states in the Brazilian northeast region, which is used in the sisal industry. Only $5 \%$ of the plant is recovered, and its residual liquid completely wasted. In this way, the aim of this research project was to investigate the larvicidal action of the juice of Agave sisalana against larvae of $A$. aegypti.

\section{Methods}

In larvicidal activity assays, fourth stage $A$. aegypti larvae were exposed to different concentrations $(1,3,6,6.5,10$ and $20 \mathrm{mg} / \mathrm{mL}$ ) of A. sisalana liquid waste dissolved in water, during 24 hours. The control group consisted of 20 fourth stage larvae, exposed to tap water for 24 hours. The experiment was performed in triplicate. The histopathological analysis was performed by staining with HE.

\section{Results and conclusions}

The A. sisalana concentrations of 1 and $3 \mathrm{mg} / \mathrm{mL}$ did not kill any larvae. However, the concentrations of 6 ,

Federal University of Paraiba, João Pessoa, Paraíba, Brazil
$6.5,10$ and $20 \mathrm{mg} / \mathrm{ml}$ respectively killed $78,78,88$ and $100 \%$ of the larvae within 24 hours. After the larvicidal activity assays, it was possible to determine the LC50 that was $5.9 \mathrm{mg} / \mathrm{mL}$. The histological alterations were confirmed by histopathological analysis, which showed lyses of the mesentery epithelial cells of larvae as well as peritrophic membrane destruction. In this way, the $A$. sisalana liquid waste constitutes an effective alternative and economically feasible for the dengue vector combat. The outcomes of our research resulted in the patent.

Published: 1 October 2014

\section{References}

1. Francis G, Kerem Z, Makkar HP, Becker K: The biological action of saponins in animal systems: a review. British Journal of Nutrition 2002, 88(6):587-605.

2. Guzmán MG, Kourí G: Dengue: an update. The Lancet Infectious Diseases 2002, 2:33-42.

3. Pechan $T$, Cohen A, Willians WP, Luthe DS: Insect feeding mobilizes a unique plant defense protease that disrupts the peritrophic matrix of cartepillars. Proceedings of the National Academy of Sciences 2002, 99(13):319-23.

doi:10.1186/1753-6561-8-S4-P5

Cite this article as: Nunes et al:: Larvicidal activity of Agave sisalana against Aedes aegypti mosquito, the dengue vector. BMC Proceedings 2014 8(Suppl 4):P5

Submit your next manuscript to BioMed Central and take full advantage of:

- Convenient online submission

- Thorough peer review

- No space constraints or color figure charges

- Immediate publication on acceptance

- Inclusion in PubMed, CAS, Scopus and Google Scholar

- Research which is freely available for redistribution 